\title{
Nutrient digestibility of green seaweed Ulva meal and the influence on growth performance of Nile tilapia (Oreochromis niloticus)
}

\author{
Lusi Herawati Suryaningrum*, Reza Samsudin \\ Research Institute for Freshwater Aquaculture and Fisheries Extension (RIFAFE), Sempur 1, Bogor, West Java, Indonesia
}

\section{A B S T R A C T}

\begin{abstract}
Green seaweed Ulva had a high growth rate and spread in all of Indonesian waters. Species Ulva had a complete nutrient content that made it potential to be used as an alternative fish feed ingredient. This experiment was conducted in two series of trial, digestibility measurement of Ulva meal and its effects on the growth performance of the Nile tilapia (O. niloticus). In measuring the nutrient digestibility, a protein rich diet was formulated with a test diet in which $30 \%$ of the reference diet was replaced with Ulva meal, used $\mathrm{Cr}_{2} \mathrm{O}_{3}$ as an inert marker. Fish with initial weight about $16 \pm 0.35 \mathrm{~g}$ were stocked with a density of 15 fish per aquarium and collecting faeces is carried out until sufficient sample was available for analysis. The growth trial was conducted using a completely randomized design with four treatments and three replications. The experimental diets were $U_{0}(U / v a 0 \%), U_{10}(U l v a 10 \%), U_{20}(U l v a 20 \%)$ and $\mathrm{U}_{30}$ (Ulva $30 \%$ ). The Nile tilapia with an average body weight of $3.42 \pm 0.01 \mathrm{~g}$, were stocked into the $60 \times 50 \times 50 \mathrm{~cm}$ aquaria with 25 fish in each tank and cultured for 60 days. Fish were fed three times daily on those diets at satiation level. The parameters which evaluated were specific growth rate, protein retention, lipid retention, feed efficiency, survival rate and blood hematology of the Nile tilapia. The results of digestibility measurement showed that Ulva meal had acceptable nutrients as an ingredient in Nile tilapia diet.

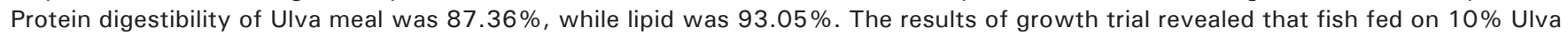
meal tended to have highest growth performance than those fed to the control, while the survival rate and fish health seemed not to be affected directly $(P>0.05)$.
\end{abstract}

Keywords: Growth performance; Nile tilapia; Nutrient digestibility; Survival rate; Ulva

\section{INTRODUCTION}

The need for alternative sources for aquafeeds has recently renewed interest in ingredients that are generally derived from plant origin, mainly terrestrial and also aquatic (Wassef et al., 2013). The use of local ingredients is an effort to reduce dependency on imported ones. The research for alternative materials has been going on for two decades (Viscaino et al., 2015). Local ingredients which have been widely used in fish feed were cassava leaves (Madalla et al., 2016), cassava peel (Tachnia et al., 2016), rubber seeds (Femi et al., 2016) and cake palm oil (Adjanke et al., 2016). However, the use of local ingredients of terrestrial plants is constrained by the high content of crude fiber and the presence of anti nutrient factors such as phytic acid and cyanide, so other materials need to be sought as fish feed ingredients.
Seaweed has potentially to be used as an alternative of fish feed ingredient because it has complete nutrient content. Seaweed has a nutrient composition that varies greatly depending on season, geography, species, harvest age and environmental conditions (Denis et al., 2010). The main content of seaweed in general is a complex of polysaccharide, protein, lipid, ash, vitamins and minerals. Seaweed is easier to digest than lignocellulosic materials from terrestrial plant (Smith et al., 2010). Research that has been carried out in order to use seaweed as fish feed ingredient, has interesting results. Pratiwy et al. (2018) stated that the addition of $8 \%$ Sargassum meal gave the best results on the growth of Nile tilapia. Then Shapawi and Zamry (2016) reported that 50\% inclusion of seaweed meal from Kappaphycus alvareziii, Eucheuma denticulatum and Sargassum polycystum in Lates calcarifer diet, did not affect the growth and feed conversion ratio. Younis et al. (2018) stated that the use of red algae (Gracilaria arcuate) less than 20\%

\footnotetext{
*Corresponding author:

Lusi Herawati Suryaningrum. Research Institute for Freshwater Aquaculture and Fisheries Extension (RIFAFE). Sempur 1, Bogor, West Java, Indonesia. Tel: +62 251 8313200, E-mail: Iusihera@yahoo.co.id
} 
in diet, gives the best results on growth performance, feed utilization and body composition of Nile tilapia.

In the past decade, species from the genus Ulva have been widely used because of the high bioactive component with diverse biological activities (Taboada et al., 2010). Suryaningrum et al. (2017) reported that seaweed Ulva which was taken from Pulang Sawal Beach, Yogyakarta Special Region, Republic of Indonesia has a protein content of $13.65 \%, 0.53 \%$ lipid, $33.19 \%$ ash, $9.2 \%$ crude fiber and carbohydrate (NFE) 43.51\%. Anti nutrient factors which are usually found in plant such as oxalate, phytate, tannin and carbonate are not found in Ulva (Abirami and Kowsalya, 2011). Amino acids contained in Ulva most are essential amino acids (Benjama and Masniyom, 2011), whereas fatty acid types that have double bonds reach up to $50 \%$ of all detected fatty acids (Tabarsa et al., 2012).

Seaweed Ulva thrives and have a very fast growth rate in locations that provide the abundance nutrients (Wassef et al., 2013). The results of the study which conducted by Chen et al. (2015) reported that the growth rate of Ulva reached $5.22 \%$ day $^{-1}$. Even some areas report the uncontrolled of Ulva growth (Li et al., 2016). Based on nutrient content and growth rate, Ulva potential to be used as fish feed ingredient. This study aims to evaluate the digestibility of Ulva meal and its influence on the growth and survival rate of Nile tilapia (O. niloticus).

\section{MATERIALS AND METHODS}

The present experiment was carried out in Fish Nutrition and Feed Technology Laboratory, Research Institute for Freshwater Aquaculture and Fisheries Extension (RIFAFE), Bogor, West Java, Indonesia. This experiment was conducted in two series of trial, digestibility measurement of Ulva and growth performance of Nile tilapia fed diets with different levels of Ulva meal.

\section{Preparation of Ulva meal}

Green seaweed Ulva was collected from Binuangeun Beach, West Java, Indonesia. Seaweed was thoroughly washed with fresh water and then sun dried for $4 \mathrm{~h}$ in an oven at $60^{\circ} \mathrm{C}$ for $48 \mathrm{~h}$ until complete dryness. Then the dried seaweed milled in a mechanical grinder to obtain a homogenous powder (Fig. 1). The chemical composition of Ulva meal was determined through laboratory analysis to AOAC (2005) as shown in Table 1.

\section{Trial 1- Digestibility measurements in the Nile tilapia (O. niloticus)}

\section{Diets preparation}

The digestibility measurement was carried out based on the Takeuchi (1988) method, where the experimental diets composed of $70 \%$ reference diet and $30 \%$ of Ulva meal as an ingredient that will be tested (Table 2). The diet was formulated to satisfy nutrients requirement of Nile tiapia. Chromic oxide $\left(\mathrm{Cr}_{2} \mathrm{O}_{3}\right)$ was used as an inert marker at $0.6 \%$ in reference and test diets. All ingredients thoroughly mixed until homogenous. The $2 \mathrm{~mm}$ diameter pellets were wetextruded, dried in a convection oven at $60^{\circ} \mathrm{C}$ for $12 \mathrm{~h}$ and sealed in plastic bags until used.

\section{Faeces collection}

Nile tilapia (O. niloticus) were obtained from the Research Station for Freshwater Fisheries Germplasm, Cijeruk, Bogor. Before starting trial, fish were acclimated and fed with the reference diet for 7 days. At the beginning of the experiment, fish with initial weight about $16 \pm 0.35 \mathrm{~g}$ were stocked with a density of 15 fish per aquarium. The system was provided with continuos aeration to maintain the dissolved oxygen level above saturation. Fish fed 7 days before the beginning of faecal collection. Faecal collected dried in an oven with a temperature of $60^{\circ} \mathrm{C}$ for $48 \mathrm{~h}$, sealed in plastic container and stored in $5^{\circ} \mathrm{C}$ until use (Fig. 2). Collecting faeces is carried out until sufficient sample was available for chemical analysis. The diet digestibility was determined by equation proposed by Goddard and McLean (2001). The ingredient digestibility was determined by equation proposed by Bureau and Hua (2006).
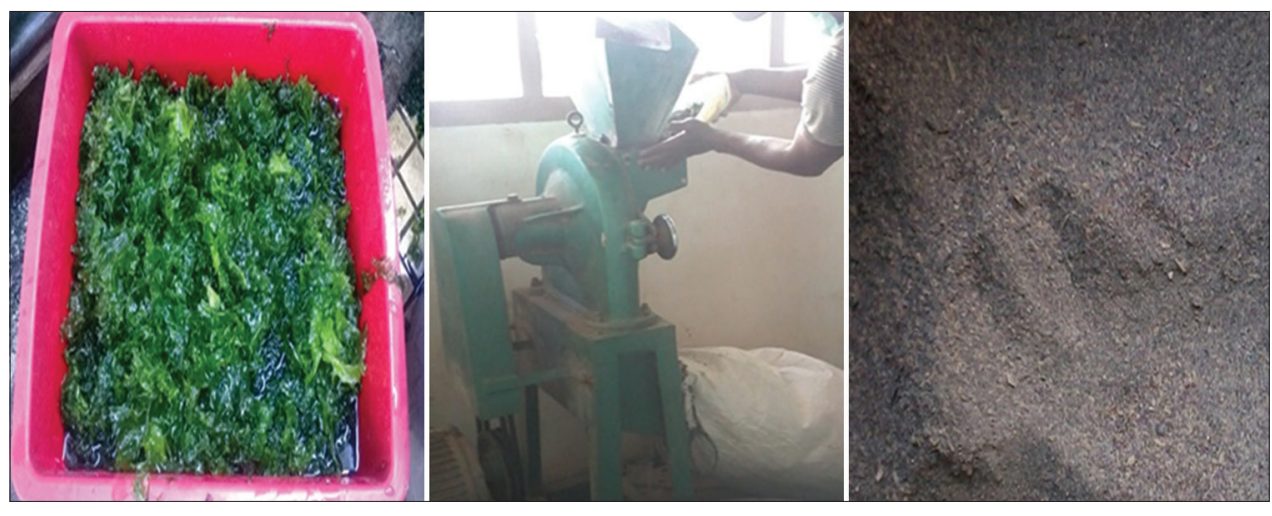

Fig 1. Preparation of Ulva meal. 
Table 1: Nutrient composition of ulva meal

\begin{tabular}{|c|c|}
\hline Parameters & (\% dry matter) \\
\hline Moisturize & $7.85 \pm 0.03$ \\
\hline Crude protein & $15.21 \pm 0.05$ \\
\hline Lipid & $1.07 \pm 0.07$ \\
\hline Ash & $27.84 \pm 0.11$ \\
\hline Crude fiber & $10.34 \pm 0.27$ \\
\hline Nitrogen Free Extract (NFE) ${ }^{a}$ & $45.56 \pm 0.39$ \\
\hline Gross Energy $(\mathrm{GE})^{\mathrm{b}}$ & $282.38 \pm 4.26$ \\
\hline
\end{tabular}

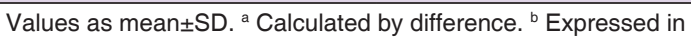

$\mathrm{kcal} . \mathrm{g}^{-1}$, calculated according to energy values of $1 \mathrm{~g}$ protein $=5.6 \mathrm{kcal}$,

$1 \mathrm{~g} \mathrm{lipid}=9.4 \mathrm{kcal}, 1 \mathrm{~g}$ carbohydrate $=4.1 \mathrm{kcal}$ (Watanabe, 1988).

Table 2: Ingredient of the reference and test diets (\% dry matter)

\begin{tabular}{lcc}
\hline Ingredients & Reference diet & Test diet \\
\hline Basal diets & 96.4 & 66.4 \\
Ulva meal & 0.0 & 30.0 \\
$\mathrm{CMC}$ & 3.0 & 3.0 \\
$\mathrm{Cr}_{2} \mathrm{O}_{3}$ & 0.6 & 0.6 \\
Total & 100.0 & 100.0 \\
\hline
\end{tabular}
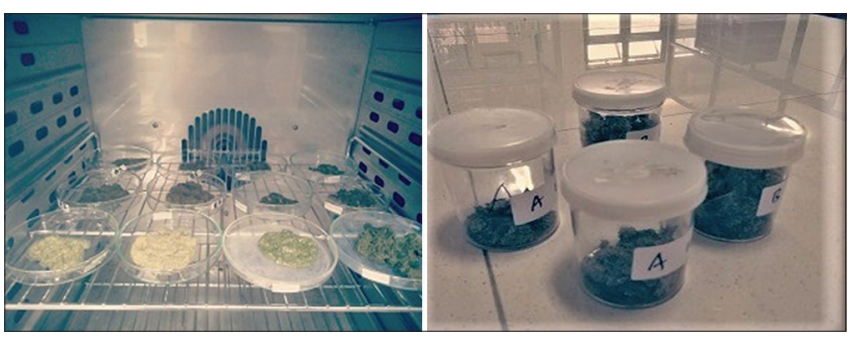

Fig 2. Faecal collection.

\section{Trial 2- Growth performance of Nile tilapia Experimental diets}

Growth performance measurement of Nile tilapia was conducted using a completely randomized design (CRD) with 4 treatments and 3 replications, i.e $\mathrm{U}_{0}$ (Ulva $0 \%$ ), $\mathrm{U}_{10}$ (Ulva 10\%), $\mathrm{U}_{20}$ (Ulva 20\%), $\mathrm{U}_{30}$ (Ulva 30\%). Those diets were isonitrogenous $(28 \pm 0.5 \%)$ and isoenergetic $\left(4100 \pm 100 \mathrm{kcal} \mathrm{kg}^{-1}\right)$ which fulfills the requirement for tilapia. The experimental diets for growth performance was shown in Table 3, while proximate analysis was in Table 4. All dietary ingredients were blended thoroughly, moistened, pelleted and dried at $60^{\circ} \mathrm{C}$ for $24 \mathrm{~h}$. Diets were stored in hermetic plastic until fed (Fig. 3).

\section{Experimental fish, rearing condition and feeding regime} The Nile tilapia (O. niloticus) were collected from the Research Station for Freshwater Fisheries Germplasm, Cijeruk, Bogor. Fish were acclimatized for 14 days prior to the feeding trial. Each experimental diet was fed tro triplicate group of 25 Nile tilapia with an average initial body weight of $3.27 \pm 0.11 \mathrm{~g}$. The growth trial lasted for 60 days and was carried out in $150 \mathrm{~L}$ glass aquaria which equipped with a recirculation system (Fig. 4). The diets were fed to apparent satiation level three times daily. The weight of each fish was measured at the beginning and at the end
Table 3: Ingredient composition of experimental diets (\% dry matter) containing ulva meal in different levels

\begin{tabular}{lcccc}
\hline Ingredients & \multicolumn{4}{c}{ Experimental diets } \\
\cline { 2 - 5 } & $\mathbf{U}_{0}$ & $\mathbf{U}_{10}$ & $\mathbf{U}_{20}$ & $\mathbf{U}_{30}$ \\
\hline Fish meal & 17.12 & 16.49 & 15.91 & 13.80 \\
Ulva meal & 0.00 & 10.00 & 20.00 & 30.00 \\
Soyabean meal & 35.08 & 30.55 & 26.00 & 23.00 \\
Wheat bran meal & 37.84 & 33.00 & 28.00 & 23.00 \\
Cassava meal & 3.00 & 3.00 & 3.00 & 3.00 \\
Fish oil & 0.60 & 0.50 & 0.50 & 0.50 \\
Corn oil & 0.00 & 0.20 & 0.40 & 0.60 \\
Vegetable oil & 3.30 & 3.20 & 3.10 & 3.00 \\
Vitamin/mineral mix & 3.06 & 3.06 & 3.06 & 3.06 \\
Total & 100.00 & 100.00 & 100.00 & 100.00 \\
\hline
\end{tabular}

Table 4: Proximate analysis of experimental diets (\% dry matter) containing ulva meal in different levels

\begin{tabular}{lcccc}
\hline Parameters & \multicolumn{4}{c}{ Experimental diets } \\
\cline { 2 - 5 } & $\mathbf{U}_{0}$ & $\mathbf{U}_{10}$ & $\mathbf{U}_{20}$ & $\mathbf{U}_{30}$ \\
\hline Crude protein & 28.83 & 28.76 & 28.65 & 28.61 \\
Lipid & 5.79 & 5.96 & 5.65 & 5.86 \\
Ash & 10.01 & 11.21 & 12.50 & 14.05 \\
Crude fiber & 5.63 & 5.62 & 5.58 & 5.35 \\
Nitrogen Free Extract (NFE) & 49.73 & 48.46 & 47.63 & 46.13 \\
Gross Energy (GE) & 4197.73 & 4157.66 & 4088.33 & 4044.37
\end{tabular}

Values as mean \pm SD. ${ }^{a}$ Calculated by difference. ${ }^{b}$ Expressed in

$\mathrm{kcal} . \mathrm{g}^{-1}$, calculated according to energy values of $1 \mathrm{~g}$ protein $=5.6 \mathrm{kcal}$, $1 \mathrm{~g} \mathrm{lipid}=9.4 \mathrm{kcal}, 1 \mathrm{~g}$ carbohydrate $=4.1 \mathrm{kcal}$ (Watanabe, 1988) .

of the experimental period. Water quality parameters were monitored and remained at acceptable levels throughout the experimental period, temperatures ranged $27-29^{\circ} \mathrm{C}, \mathrm{pH}$ 6.9-7.3 and dissolved oxygen 6.1-6.9 mg.. $\mathrm{L}^{-1}$. Hematology parameters of experimental fish was carried out at the end of the experimental period.

\section{Determination of growth parameters}

Following parameters calculated from the data were: feed efficiency $(\mathrm{FE})=(\mathrm{Wt}-\mathrm{Wo}) \times \mathrm{F}^{-1}$, protein retention $(\mathrm{PR})=100 \times(\mathrm{Pt}-\mathrm{Po}) \times \mathrm{P}^{-1}$, lipid retention $(\mathrm{LR})=100 \times(\mathrm{Lt}-$ Lo) $\mathrm{x} \mathrm{L}^{-1}$; specific growth rate $(\mathrm{SGR})=100 \mathrm{x}(\ln \mathrm{Wt}-\ln \mathrm{Wo})$ $\mathrm{xt}^{-1}$, survival rate $(\mathrm{SR})=100 \mathrm{x}$ (final number of fish $\mathrm{x}$ initial number of fish $\left.{ }^{-1}\right)$. The symbols in the equations are as the follows: Wo and Wt - the initial and the final average fish body mass (g); t-number of days of feeding trial; F-the total amount of feed per fish consumed during growth test (g); $\mathrm{P}$ - protein intake (g); $\mathrm{Pt}$ - final protein content in fish body (g); Po-initial protein content in fish body $(\mathrm{g})$; Lt—final lipid content in fish body (g); Lo-initial lipid content in fish body $(\mathrm{g})$; L-lipid intake $(\mathrm{g})$.

\section{Chemical analysis}

Proximate analysis was carried out on feedstuffs samples, experimental diets, dried feces and whole-body fish before and after experimental period using the AOAC method (2005). Analysis of chromium $\left(\mathrm{Cr}_{2} \mathrm{O}_{3}\right)$ in experimental 
diet and dried faeces was carried out using the Takeuchi (1988) method. The following methodology was adopted for blood analysis: erythrocytes and leucocytes (Blaxhall and Daisley, 1973), hemoglobin (Wedemeyer and Yasutake, 1977) and hematocrit (Anderson and Siwicki, 1993).

\section{Statistical analysis}

The value of parameters was presented as means \pm standard deviation (SD). Experimental data were analized as one-way completely randomized designs to ANOVA $(\mathrm{P}<0.05)$ and Duncan's multiple range test using SPSS version 23.00 statistical package.

\section{RESULTS}

The results revealed that Ulva meal had acceptable nutrient content as an ingredient in Nile tilapia diet. Lipid showed the highest, then followed by protein. These result was exhibited in Table 5.

Growth performance and feed utilization of diets during experimental period is shown in Table 6. The results showed that the feed intake was not significantly different for all

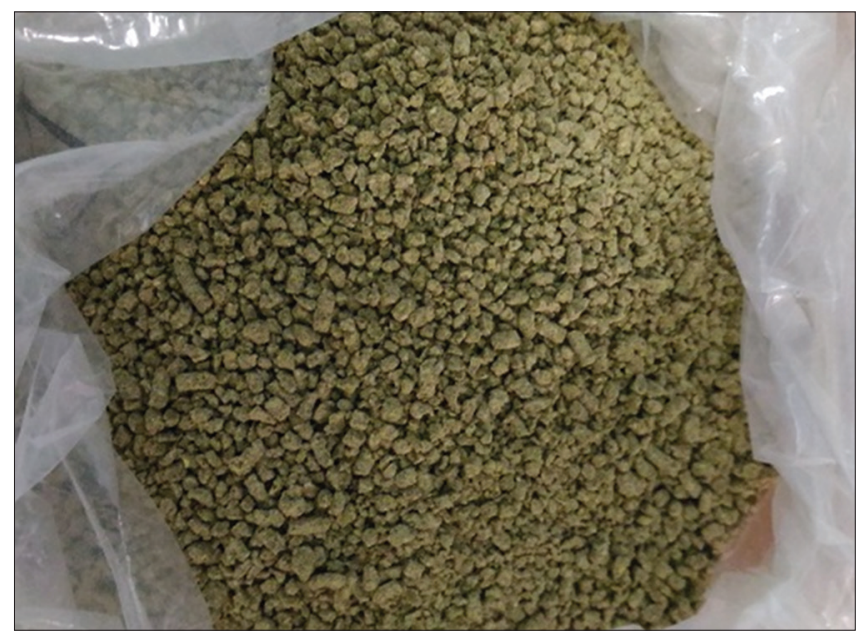

Fig 3. Experimental diet.

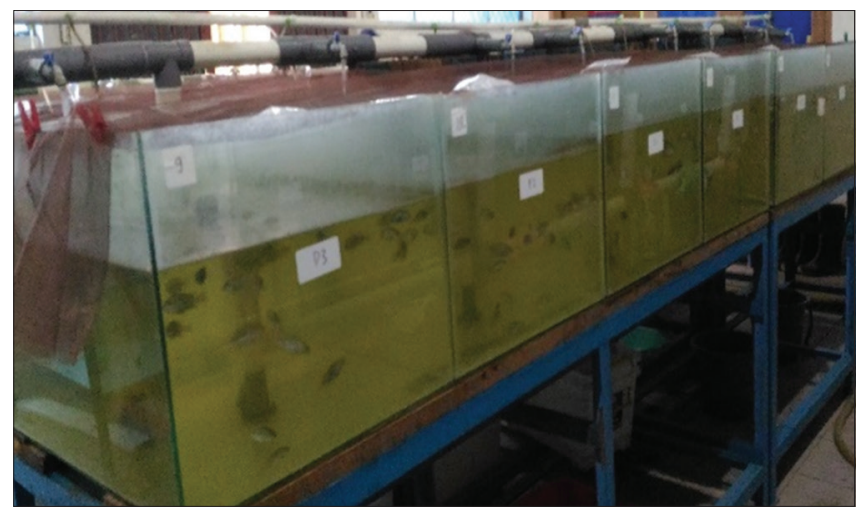

Fig 4. Growth trial. treatments $(\mathrm{P}>0.05)$. During the 60 days of experimental period, the weight of tilapia increased 5.62 to 7.03 times from the initial weight. Fish fed with diet containing 10\% Ulva $\left(\mathrm{U}_{10}\right)$ had the largest body weight at 7.03 times at the end of experimental period $(\mathrm{P}<0.05)$. While fish fed with diet containing of $30 \%$ Ulva $\left(\mathrm{U}_{30}\right)$ had the lowest growth $(\mathrm{P}<0.05)$. Feed efficiency, protein retention and specific growth rate have the same pattern. Thus the tilapia fed with diet containing of $10 \%$ Ulva $\left(\mathrm{U}_{10}\right)$ has the highest growth performance when compared with other treatments $(\mathrm{P}<0.05)$. Lipid retention in fish bodies tends to have inversely proportional patterns compared to other growth performance parameters. The survival rate of tilapia ranges from 98.00 to $98.67 \%$ and not significantly different for all treatments $(\mathrm{P}>0.05)$

Blood hematology parameters can be used to diagnose fish health status. The results of hematological measurement of experimental fish are shown in Table 7 . Total erythrocytes ranged from 1.34-2.79 x $10^{6} \mathrm{~mm}^{-3}$.cells, leucocytes 8.04

Table 5: Nutrient digestibility of ulva meal in the nile tilapia

\begin{tabular}{lc}
\hline Parameters & $(\%)$ \\
\hline Protein & $87.36 \pm 3.14$ \\
Lipid & $93.05 \pm 1.39$ \\
\hline Values as mean \pm SD &
\end{tabular}

Table 6: Growth parameters and survival rate of Nile tilapia fed diets with different levels of Ulva meal

\begin{tabular}{lcccc}
\hline Parameters & \multicolumn{4}{c}{ Experimental diets } \\
\cline { 2 - 5 } & $\mathbf{U}_{0}$ & $\mathbf{U}_{10}$ & $\mathbf{U}_{20}$ & $\mathbf{U}_{30}$ \\
\hline $\mathrm{W}_{0}\left(\mathrm{~g} \mathrm{fish}^{-1}\right)$ & $3.42 \pm 0.01^{\mathrm{a}}$ & $3.42 \pm 0.00^{\mathrm{a}}$ & $3.41 \pm 0.01^{\mathrm{a}}$ & $3.42 \pm 0.01^{\mathrm{a}}$ \\
$\mathrm{W}_{\mathrm{t}}\left(\mathrm{g} \mathrm{fish}^{-1}\right)$ & $21.52 \pm 0.54^{\mathrm{b}}$ & $24.04 \pm 0.22^{\mathrm{c}}$ & $21.84 \pm 1.91^{\mathrm{b}}$ & $19.21 \pm 0.50^{\mathrm{a}}$ \\
$\mathrm{FI}\left(\mathrm{g} \mathrm{fish}^{-1}\right)$ & $21.20 \pm 0.15^{\mathrm{a}}$ & $20.95 \pm 0.08^{\mathrm{a}}$ & $20.60 \pm 0.08^{\mathrm{a}}$ & $20.67 \pm 014^{\mathrm{a}}$ \\
$\mathrm{FE}(\%)$ & $84.82 \pm 1.15^{\mathrm{b}}$ & $88.55 \pm 1.16^{\mathrm{c}}$ & $83.70 \pm 0.76^{\mathrm{b}}$ & $76.41 \pm 0.49^{\mathrm{a}}$ \\
$\mathrm{PR}(\%)$ & $35.17 \pm 1.68^{\mathrm{b}}$ & $37.94 \pm 1.24^{\mathrm{c}}$ & $35.37 \pm 0.58^{\mathrm{b}}$ & $32.33 \pm 0.88^{\mathrm{a}}$ \\
LR (\%) & $45.11 \pm 0.98^{\mathrm{b}}$ & $42.65 \pm 0.80^{\mathrm{a}}$ & $44.61 \pm 0.36^{\mathrm{b}}$ & $47.47 \pm 0.47^{\mathrm{c}}$ \\
SGR (\% & $3.07 \pm 0.05^{\mathrm{b}}$ & $3.25 \pm 0.02^{\mathrm{c}}$ & $3.02 \pm 0.03^{\mathrm{b}}$ & $2.88 \pm 0.04^{\mathrm{a}}$ \\
g.day & & & & \\
SR $(\%)$ & $98.67 \pm 2.31^{\mathrm{a}}$ & $98.67 \pm 2.31^{\mathrm{a}}$ & $98.00 \pm 2.00^{\mathrm{a}}$ & $98.67 \pm 2.31^{\mathrm{a}}$ \\
\hline
\end{tabular}

Keterangan: Values as mean \pm SD. Values in the same line with different superscript letters are significantly different $(P<0.05) . W_{0}=$ initial weight, $\mathrm{W}_{\mathrm{t}}=$ final weight, $\mathrm{FI}=$ feed intake, $\mathrm{FE}=$ feed efficiency, $\mathrm{PR}=$ protein retention, $\mathrm{LR}=$ lipid retention, $\mathrm{SGR}=$ specific growth rate, $\mathrm{SR}=$ survival rate .

Table 7: Hematology parameters of Nile tilapia fed diets with different levels of ulva meal

\begin{tabular}{|c|c|c|c|c|}
\hline \multirow[t]{2}{*}{ Parameters } & \multicolumn{4}{|c|}{ Pakan uji } \\
\hline & $\mathrm{U}_{0}$ & $U_{10}$ & $U_{20}$ & $\mathbf{U}_{30}$ \\
\hline $\begin{array}{l}\text { Erythrocytes } \\
\left(10^{6} \mathrm{~mm}^{-3}\right)\end{array}$ & $1.34-2.11$ & $1.92-2.13$ & $2.51-2.76$ & $2.36-2.79$ \\
\hline $\begin{array}{l}\text { Leucocyte } \\
\left(\times 10^{4} \text { cell. }\right. \\
\left.\mathrm{mm}^{-3}\right)\end{array}$ & $8.74-9.34$ & $8.43-9.03$ & $8.81-9.66$ & $8.04-8.41$ \\
\hline $\begin{array}{l}\text { Hemoglobin } \\
\left(\text { g. } \text { L }^{-1}\right)\end{array}$ & $6.11-6.79$ & $5.65-5.99$ & $6.95-7.83$ & $6.08-6.54$ \\
\hline $\begin{array}{l}\text { Hematocrit } \\
(\%)\end{array}$ & $28.14-28.82$ & $26.17-29.89$ & $32.11-34.28$ & 29.47-33.19 \\
\hline
\end{tabular}


$9.66 \times 10^{4} \mathrm{~mm}^{-3}$.cells, hemoglobin 5.65-7.83 g.. $\mathrm{L}^{-1}$ and hematocrit $26.17-34.28 \%$.

\section{DISCUSSIONS}

The determination of nutrient digestibility is the first step in evaluating the potential of an ingredient for use in the diet of an aquaculture species (Zhou and Yue, 2012). Digestibility measurement shows the amount of nutrients that can be digested and used by fish for metabolism and growth (NRC 2011). Tilapia could digest protein of Ulva at $87.36 \pm 3.14 \%$. This was not much different from pollard which is equal to $82.87 \%$ (Ribeiro et al., 2011). This result is in line with the research of Koprucu and Ozdemir (2005) who reported that protein digestibility of some ingredients in Tilapia ranged from 75-95\%. Koprucu and Ozdemir (2005) and Ribeiro et al. (2011) reported that protein digestibility is an indicator of amino acid digestibility.

Tilapia could digest lipid of Ulva meal at $93.05 \pm 1.39 \%$. This result is in line with Sklan et al. (2004) which reported that lipid digestibility in tilapia ranged from 7.20 to $97.50 \%$. Although the lipid content in seaweed is relatively low, but lipid digestibility depends on the composition of fatty acids and the degree of saturation. More carbon atoms in the chain of fatty acids, will decrease the digestibility of lipid, and more double bonds will increase their digestibility. Tabarsa et al. (2012) reported that about $50 \%$ of the fatty acids found in Ulva is group of $n-3$ and n-6 PUFA. In addition, high lipid digestibility is also related to the high activity of lipase enzymes in Nile tilapia (Sargent et al., 1989).

The results of the digestibility measurement showed that tilapia is capable of digesting nutrients contained in Ulva meal, so it can be used as feed ingredients for Nile tilapia. Then Ulva meal used up to $30 \%$ in diet to measure the effect of nutrients inside on the growth performance and survival rate of Nile tilapia.

The results of variance analysis showed that using Ulva meal up to $30 \%$ in diet did not affect survival rate of tilapia significantly $(\mathrm{P}>0.05)$ (Table 6). It showed that the addition of Ulva meal does not have a negative influence on the water quality parameters, so it can support the survival rate of tilapia.

The amount of feed intake that was not significantly different $(\mathrm{P}>0.05)$ showed that the addition of Ulva meal up to $30 \%$ in diet does not affect palatability and appetite for fish. Fish fed with diet containing $10 \%$ of Ulva meal gives the best specific growth rate compared to other treatments $(\mathrm{P}<0.05)$. It showed that fish fed with diet containing 10\% of Ulva meal is more optimal in utilizing energy from non-protein energy sources (lipids and carbohydrates) for metabolic and maintenance activities, so the protein contained in diet can be used for growth (Hardy 2010; Sikorska et al., 2012). It meaning more efficient of feed utilization. This is supported by data on protein retention, feed efficiency and lipid retention. Protein retention in fish fed with diet containing $10 \%$ of Ulva meal have the highest value compared to other treatments, meaning that the protein stored more in the whole-body fish. The more efficient use of diet is shown by data on feed efficiency (Table 6). Lipid retention value in Nile tilapia decreases along with the increasing of Ulva meal in diet. Setiawati et al. (2003) reported that the decrease in lipid retention indicates that fish can utilize carbohydrates and lipids well, so the protein in diet can be used by cell for protein synthesis. The maximum use of energy derived from lipid and carbohydrates can support the use of protein as a component of fish growth. The growth of experimental fish can also be seen from their weight gain.

The results also showed that the utilization of Ulva meal in diet by $30 \%$ produces low growth which is significantly different $(\mathrm{P}<0.05)$ with control. This is reinforced by the low feed efficiency value. The growth of Nile tilapia is getting lower along with the increasing Ulva meal in diet, it caused by the higher ash content in the experimental diets (Table 4). According to the statement of Sugiura et al. (1998), consumption of high ash content in diet decreased nutrient absorption and growth.

The decrease in fish growth caused by the use of seaweed in diets was found in previous research results. The use of Ulva rigida seaweed in diet by $20 \%$ cause the lower goldfish growth (Diler et al., 2007). Tilapia diet with containing of $15 \%$ Ulva rigida cause growth and feed intake as well as low energy utilization (Kut-Guroy et al., 2007). Low growth, survival rate and body composition also occur in rainbow trout with $10 \%$ of Sargassum ilicifolium in diet (Zamannejad et al., 2016). Differences in the optimal level of supplementation of seaweed in fish diet can occur due to differences in fish species, size of fish and different research conditions.

Hematological parameters are used to detect the health status of fish (Al-Attar 2005). Fish infected with the disease will experience changes in the number of erythrocytes, leukocytes, hemoglobin and hematocrit. The test results showed that the hematology of fish all treatments was in the range of the value of healthy tilapia. Healthy tilapia has a number of erythrocytes ranging from $2.0 \times 10^{4}$ $3.0 \times 10^{6} \mathrm{~mm}^{-3}$ cells; leucocytes $2.0 \times 10^{4}-1.5 \times 10^{5} \mathrm{~mm}^{-3}$ cells; hemoglobin 5.05-8.33 g\% (Salasia et al., 2001) and hematocrit 5-60\% (Sasongko 2001). Overall, the results of 
the blood hematology test showed that the utilization of Ulva up to $30 \%$ in diet proved not to affect the fish health.

The results in this study are in line with several previous research. Natify et al. (2015) reported that the use of Ulva up to $10 \%$ in Nile tilapia diet, proved not to interfere with growth performance, feed conversion, protein efficiency ratio and somatic index. The results of the study by Mahasu et al. (2016) reported that the use of Ulva lactuca up to $12 \%$ in Nile tilapia diet not decreased growth performance, while the study of Azaza et al. (2008) reported that the use of Ulva meal in tilapia diet up to $20 \%$ does not have a negative impact on growth performance, survival, feed conversion and protein efficiency ratio, use of Ulva meal will have a negative impact on growth when the inclusion level in diets reaches $30 \%$.

\section{CONCLUSION}

The result of this study showed that green seaweed Ulva was found to be digested and utilized by Nile tilapia. Dietary inclusion at 10\% Ulva meal could be potentially used and further investigations are required to evaluate the optimum dietary inclusion level between $10-20 \%$ of Ulva meal in Nile tilapia diets to enhance growth performance, feed utilization and survival rate.

\section{ACKNOWLEDGEMENT}

The authors thankful to the technicians of Department of Fish Nutrition and Feed Technology, Research Institute for Freshwater Aquaculture and Fisheries Extension (RIFAFE), Bogor, West Java, Indonesia, for their contribution and continuous help throughout the experimental period, and special cordial thanks to Prof. Dr. Ir. Mas Tri Djoko Sunarno, MS for his support. This research was funded by RIFAFE, Ministry of Marine Affairs and Fisheries, Republic of Indonesia.

\section{Author's contributions}

Lusi Herawati Suryaningrum, collected the experimental data, interpreted \& analyzed the results and drafted the manuscripts. Reza Samsudin, assisted in conducting the experiments, paper writing and corrected the englist text.

\section{REFERENCES}

Abirami, R. G. and Kowsalya, S. 2011. Nutrient and nutraceutical potentials of seaweed biomass Ulva lactuca and Kappaphycus alvarezii. J. Agric. Sci. Tech. 5: 1939-1950.

Adjanke, A., K. Tona, C. Melecony, I. I. Toko and M. Gbeassor. 2016. Effect of dietary inclusion of palm kernel meal on feed intake, growth and body composition of Nile Tilapia, Oreochromis niloticus reared in concrete tanks in Togo. Int. J. Fish. Aquat.
Stud. 4: 642-646.

Al-Attar, A. M. 2005. Changes in haematological parameters of the fish Oreochromis niloticus treated with sublethal concentration of cadmium. Pak. J. Biol. Sci. 8: 421-424.

Anderson, D. P. and A. K. Siwicki. 1993. Basic Hematology and Serology for Fish Health Programs. Paper Presented in $2^{\text {nd }}$ Symposium on Diseases in Asian Aquaculture Aquatic Animal Health and the Environment, Phuket, Thailand, p. 17.

AOAC. 2005. Official Methods of the Association of Official Analytical Chemists. $16^{\text {th }}$ ed. Association of Official Analytical Chemists, Arlington.

Azaza, M. F., Ksouri, J., Dhraief, M. N., Brini, B., Abdelmouleh, A. and Kraiem, M. M. 2008. Growth of Nile tilapia (Oreochromis niloticus) fed with diets containing graded levels of green algae Ulva meal (Ulva rigida) reared in geothermal waters of southern Tunisia. J. App. Ich. 24: 202-207.

Blaxhall, P. C. and K. W. Daisley. 1973. Routine haematological methods for use with fish blood. J. Fish Biol. 5: 577-581.

Bureau, D. P. and K. Hua. 2006. Letter to the editor of Aquaculture. Aquaculture. 252: 103-105.

Chen, B., D. Zou and H. Jiang. 2015. Elevated $\mathrm{CO}_{2}$ exacerbats competition for growth and photosynthesis between Gracilaria lemaneiformis and Ulva lactuca. Aquaculture. 443: 49-55.

Denis, C., M. Morancais, M. Li, E. Deniaud, P. Gaudin, G. WielgoszCollin, G. Barnathan, P. Jaouen and J. Fleurence. 2010. Study of the chemical composition of edible red macroalgae Grateloupiaturuturu from Brittany (France). Food Chem. 119: 913-917.

Diler, I. A. A. Tekinay, D. Guroy, B. Guroy and M. Soyuturk. 2007. Effects of Ulva rigida on the growth feed intake and body composition of common carp, Cyprinus carpio. J. Biol. Sci. 7: 305-308.

Femi, J. F., P. S. Narottam, K. K. Jain, S. Gupta, N. Shamna, V. Phulia and D. L. Prabu. 2016. Nutritional evaluation of protein isolate from rubber seed in the diet of Labeo rohita: Effects on growth performance, nutrient utilization, whole body composition and metabolic enzymes activity. Anim. Feed Sci. Tech. 219: 189-199.

Goddard, J. S. and E. McLean. 2001. Acid-insoluble ash an inert reference material for digestibility studies in tilapia, Orechromis aureus. Aquaculture. 194: 93-98.

Hardy, R. W. 2010. Utilization of plant proteins in fish diets: Effects of global demand and supplies of fishmeal. Aquacult. Res. 41: 770776.

Koprucu, K. and Y. Ozdemir. 2005. Apparent digestibility of selected feed ingredients for Nile tilapia (Oreochromis niloticus). Aquaculture. 250: 308-316.

Kut-Guroy, K., S. Cirik, D. Guroy, F. Sanver and A. A. Tekinay. 2007. Effect of Ulva rigida and Cystoseira barbata meals as a feed additive on growth performance, feed utilization and body composition of nile tilapia Oreochromis niloticus. Turk. J. Vet. Anim. Sci. 31: 91-97.

Li, H., Y. Zhang, X. Han, X. Shi, R. B. Rivkin and L. Legendre. 2016. Growth responses of Ulva prolifera to inorganic and organic nutrients: Implications for macroalgal blooms in the Southern Yellow Sea, China. Sci. Rep. 6: 1-11.

Madalla, N., N. W. Agbo and K. Jauncey. 2016. Evaluation of ground sundried cassava leaf meal as protein source for nile tilapia Oreochromis niloticus (L) juvenile's diet. Tanzan. J. Agric. Sci. 15: $1-12$.

Mahasu, N. H., D. Jusadi, M. Setiawati and I. N. A. Giri. 2016. Potens rumput laut Ulva lactuca sebagai bahan baku pakan ikan nila Oreochromis niloticus. J. Ilmu Teknol. Kelautan Trop. 8: 259-267. 
Natify, W., M. Droussi, N. Berday, N. Araba and M. Benabid. 2015. Effect of the seaweed Ulva lactuca as a feed additive on growth performace, feed utilization and body composition of nile tilapia (Oreochromis niloticus). Int. J. Agric. Res. 7: 85-92.

NRC. 2011. National Research Council. 2011. Nutrient Requirement of Fish and Shrimp. Animal Nutrition Series. National Academies, Washington, US, p. 376.

Pratiwy, F. M., J. Kohbara and A. B. Susanto. 2018. Effectiveness of Sargassum meal as feed additive on growth performance of nile tilapia, Oreochromis niloticus. Aquac. Sci. 66: 25-31.

Ribeiro, F. B., E. A. T. Lanna, M. A. D. Bomfim, J. L. Donzele, M. Quadros and P. S. L. Cunha. 2011. True and apparent of protein and amino acids of feed in nile tilapia. Rev. Bras. Zootech. 40: 939-946.

Salasia, S. I. O., D. Sulanjar and A. Ratnawati. 2001. Studi hematologi ikan air tawar. Biologi. 2: 710-723.

Sargent, J., R. J. Henderson and D. R. Tocher. 1989. The lipids. In: J. E. Halver, (Ed.), Fish Nutrition. Academic Press, New York, US, pp. 154-209.

Sasongko, A. 2001. Biomassa Bakteri Nitrifikasi Pada Berbagai Bahan Filter Dalam Resirkulasi Aliran Tertutup dan Pengaruhnya Terhadap Kondisi Ikan: Gambaran Darah. (Master Thesis). Institut Pertanian Bogor, Indonesia.

Setiawati, M. and M. A. Suprayudi. 2003. Pertumbuhan dan efisiensi pakan ikan nila merah Oreochromis sp. yang dipelihara pada media besalinitas. Sci. Rep. 2: 27-30.

Shapawi, R and A. A. Zamry. 2016. Response of Asian seabass, Lates calcarifer juvenile fed with different seaweed-based diets. J. Appl. Anim. Res. 44: 121-125.

Sikorska, J., J. Wolnicki, R. Kaminski and V. Stolovich. 2012. Effect of different diets on body mineral content, growth, and survival of barbel, Barbus barbus (L.), larvae under controlled conditions. Arch. Pol. Fish. 20: 3-10.

Sklan, D., T. Prag and I. Lupatsch. 2004. Apparent digestibility coefficients of feed ingredients and their prediction in diets for tilapia Oreochromis niloticus x Oreochromis aureus (Teleostei, Cichlidae). Aquac. Res. 35: 358-364.

Smith, J. L., G. Summers and R. Wong. 2010. Nutrien and heavy metal content of edible seaweeds in New Zealand. J. Crop Hortic. Sci. 8(1): 19-28.

Sugiura, S. H., F. M. Dong, C. K. Rathbone and R. W. Hardy. 1998. Apparent protein digestibility and mineral availabilities in various feed ingredients for salmonid feeds. Aquaculture. 159: 177-202.

Suryaningrum, L. H., J. Dedi, M. Setiawati and M. T. D. Sunarno. 2017. Nutrient composition and apparent digestibility coefficient of
Ulva lactuca meal in the nile tilapia (Oreochromis niloticus) AACL Bioflux. 10: 77-86.

Tabarsa, M., M. Rezaei, P. Ramezan and J. R. Waaland. 2012. Chemical composition of the marine algae Gracilaria salicornia (Rhodophyta) and Ulva lactuca (Chlorophyta) as a potential food source. J. Sci. Food Agric. 10: 31-37.

Taboada, C., R. Millan and I. Miguez. 2010. Composition, nutritional aspects and effect on serum parameters of marine algae Ulvarigida. J. Sci. Food Agric. 90: 445-449.

Tachnia, M. U., G. A. Ataguba and P. O. Abuh. 2016. Replacing maize with cassava peels in diets of Oreochromis niloticus: Evaluation of feed performance and meta-analysis. AACL Bioflux. 9: 10011010.

Takeuchi, T. 1988. Laboratory work chemical evaluation of dietary nutrients. In: Watanabe T. (Ed.), Fish Nutrition and Mariculture. JICA Textbook the General Aquaculture Course, Tokyo, JP, pp. 179-233.

Viscaino, A. J., S. I. Mendes, J. L. Varela, I. Ruiz-Jarabo, R. Rico, F. I. Figueroa, R. Abdala, M. A. Morinigo, J. M. Mancera and F. J. Alarcon. 2015. Growth, tissue metabolites and digestive functionality in Sparus aurata juveniles fed different level of macroalgae, Gracilaria cornea and Ulva rigida. Aquac. Res. 47: 3224-3238.

Wassef, E. A., A. F. M. El-Sayed and E. M. Sakr. 2013. Pterocladia (Rhodophyta) and Ulva, Chloropyta) as feed supplements for European seabass, Dicentrarchus labrax L., fry. J. Appl. Phys. 25: 1369-1376.

Watanabe, T. 1988. Nutritional Energetics. In: T. Watanabe, (Ed.), Fish Nutrition and Mariculture. Japan International Cooperation Agency, Tokyo, JP. pp. 79-92.

Wedemeyer, G. A. and W. Y. Yasutake. 1977. Clinical Methods for the Assessment of the Effect on Environmental Stress on Fish Health. Technical Papers of the U.S. Fish and Wildlife Service, US Department of the Interior, pp. 1-17.

Younis, E. M., A. S. Al-Quffail, N. A. Al-Asgah, A. A. Abdel-Warith and Y. S. Al-Hafedh. 2018. Effect of dietary fish meal replacement by red algae, Gracilaria arcuata, on growth performance and body composition of Nile tilapia Oreochromis niloticus. Saudi J. Biol. Sci. 25: 198-203.

Zamannejad, N., H. Emadi and M. Hafezieh. 2016. Effects of supplementation of algae Sargassum ilicifolium on growth, survival and body composition of rainbow trout Oncorhynchus mykiss. Iran. J. Fish. Sci. 15: 194-205.

Zhou, Q. and Y. Yue. 2012. Apparent digestibility coefficients of selected feed ingredients for juvenile hybrid tilapia, Oreochromis niloticus x Oreochromis aureus. Aquac. Res. 43: 806-814. 